University of Nebraska - Lincoln

DigitalCommons@University of Nebraska - Lincoln

Agronomy \& Horticulture -- Faculty Publications

Agronomy and Horticulture Department

2012

\title{
Crop Management of Switchgrass
}

Matt A. Sanderson

USDA-ARS, Matt.sanderson@ars.usda.gov

Marty R. Schmer

USDA-ARS, University of Nebraska-Lincoln, marty.schmer@ars.usda.gov

Vance Owens

South Dakota State University, vance.owens@sdstate.edu

Pat Keyser

University of Tennessee - Knoxville, pkeyser@utk.edu

Wolter Elbersen

Wageningen Agricultural University, wolter.elbersen@wur.nl

Follow this and additional works at: https://digitalcommons.unl.edu/agronomyfacpub

Part of the Plant Sciences Commons

Sanderson, Matt A.; Schmer, Marty R.; Owens, Vance; Keyser, Pat; and Elbersen, Wolter, "Crop Management of Switchgrass" (2012). Agronomy \& Horticulture -- Faculty Publications. 551.

https://digitalcommons.unl.edu/agronomyfacpub/551

This Article is brought to you for free and open access by the Agronomy and Horticulture Department at DigitalCommons@University of Nebraska - Lincoln. It has been accepted for inclusion in Agronomy \& Horticulture -Faculty Publications by an authorized administrator of DigitalCommons@University of Nebraska - Lincoln. 


\title{
Chapter 4 \\ Crop Management of Switchgrass
}

\author{
Matt A. Sanderson, Marty Schmer, Vance Owens, \\ Pat Keyser and Wolter Elbersen
}

\begin{abstract}
Management of switchgrass for bioenergy and forage share some commonalities, of particular interest in bioenergy crop production is: (1) rapid establishment of switchgrass to generate harvestable biomass in the seeding year, (2) highly efficient management of soil and fertilizer $\mathrm{N}$ to minimize external energy inputs, and (3) harvest management to maximize yields of lignocellulose. Bioenergy cropping may entail management for multiple services in addition to biomass yield including soil $\mathrm{C}$ sequestration, wildlife habitat, landscape management, and water quality protection. Management is a critical factor especially as land classified as marginal or idle land will be emphasized for bioenergy
\end{abstract}

\author{
M. A. Sanderson ( $\square)$ \\ Northern Great Plains Research Laboratory, USDA-ARS, \\ 459 Mandan, ND 58554, USA \\ e-mail: Matt.sanderson@ars.usda.gov \\ M. Schmer \\ Agroecosystem Management Research Unit, USDA-ARS, \\ 131 Keim Hall University of Nebraska, Lincoln, NE 68583, USA \\ e-mail: Marty.schmer@ars.usda.gov \\ V. Owens \\ Plant Science Department, South Dakota State University, \\ 244C NPB, 2140-C Brookings, SD 57007, USA \\ e-mail: Vance.owens@sdstate.edu \\ P. Keyser \\ Department of Forestry, Wildlife, and Fisheries, University of Tennessee, \\ 274 Ellington Plant Sciences Bldg, Knoxville, TN, USA \\ e-mail: pkeyser@utk.edu \\ W. Elbersen \\ Food and Biobased Research, Wageningen UR, Bornse Weilanden 9, \\ Building 118, 6708 WG, Wageningen 17, 6700 AA, Wageningen, The Netherlands \\ e-mail: wolter.elbersen@wur.nl
}


production to reduce conflicts with food production. Marginal land may also be more risky. To date, there has been no long-term commercial production of switchgrass on a large scale and there is little in the way of hands-on, practical farm experience with switchgrass managed as a bioenergy crop. In this chapter, we lay out the key best management practices for switchgrass as a bioenergy crop including establishment, soil fertility, and pest management.

\subsection{Introduction}

Switchgrass management as a bioenergy crop is relatively new. Early in the development of switchgrass as a bio-energy crop it was assumed that management for bioenergy would be similar to forage management [1]. For example, it was assumed that establishment methods and weed management guidelines for switchgrass as a forage crop would work as well for its use as a bioenergy crop. Although management for bioenergy and forage share some commonalities, of particular interest in bioenergy crop production is: (1) rapid establishment of switchgrass to generate harvestable biomass in the seeding year (2) highly efficient management of soil and fertilizer $\mathrm{N}$ to minimize external energy inputs, and (3) harvest management to maximize yields of lignocellulose. Harvest management may differ the most between bioenergy and forage cropping because the goal is to maximize yields of lignocellulose in bioenergy rather than to optimize forage yield and forage quality. However, extension material for establishing and managing switchgrass for bioenergy has been developed based on the best-available information [2]

Bioenergy cropping may entail management for multiple services in addition to biomass yield including soil $\mathrm{C}$ sequestration, wildlife habitat, landscape management, and water quality protection. Management is a critical factor especially as land classified as marginal or idle land will be emphasized for bioenergy production to reduce conflicts with food production. Marginal land may also be more risky.

Switchgrass has been grown for grazing, hay, and conservation uses for decades and a sizable body of scientific and practical information has been accumulated [3-5]. To date, there has been no long-term commercial production of switchgrass on a large scale and there is little in the way of hands-on, practical farm experience with switchgrass managed as a bioenergy crop. Most of the technical information on the management of switchgrass as a bioenergy crop has come from small-plot research studies, pilot-scale demonstration projects of a few acres, and a handful of field- and farm-scale demonstration projects, such as the Chariton River Valley project in southern Iowa and the Tennessee Biofuels Initiative, ${ }^{1}$ which includes 6,000 acres $(2,400 \mathrm{ha})$ of switchgrass in eastern Tennessee.

\footnotetext{
1 http://www.iowaswitchgrass.com/; http://renewablecarbon.tennessee.edu/Partners.html
} 
In this chapter, we lay out the key best management practices for switchgrass as a bioenergy crop including establishment, soil fertility, and pest management. Where management protocols translate well from and are firmly founded in forage management, we briefly summarize and direct the reader to the appropriate authoritative source.

\subsection{Strategic Planning for Bioenergy Crop Management}

As mentioned at the outset, there is no large-scale production of switchgrass for bioenergy. When bioenergy cropping matures, however, farmers will need to do some strategic planning regarding production systems. For example, the first planning decision the farmer may face is whether or not to grow switchgrass for bioenergy. Economic considerations (e.g., price paid for biomass, costs of production) will certainly drive that decision but other considerations, such as flexibility to grow other crops in rotation or to manage switchgrass as a forage crop to take advantage of other markets, will affect decisions as well. Knowledge of switchgrass production will also influence decision making. A survey of Tennessee farmers in 2005 indicated that farmers were unfamiliar with switchgrass; however, nearly a third of those surveyed would grow switchgrass if it were profitable. Some of their concerns included the need for technical assistance to grow and manage switchgrass and the lack of developed markets [6]. In a survey of Illinois farmers, most respondents indicated that growing perennial grasses for bioenergy may be worthwhile, however, they had limited knowledge of the grasses and how to grow or manage them [7]. Some of their concerns regarding production included lack of a local market for the biomass and a hesitancy to replace annual row crops with perennial grasses. Farmers who rented land were reluctant to consider perennial grasses because their landlord may not approve of the cropping system change. Most respondents stated that perennial grasses would fit best on their marginal cropland.

The option to use switchgrass both as cattle forage and biomass for energy could offer an attractive incentive for farmers wherever livestock production is an important enterprise. Flexibility in its use could also provide an incentive to adopt switchgrass production as a new enterprise [8].

Strategic planning also includes considerations for site selection for growing switchgrass. Site selection criteria may include suitability of soils for switchgrass production among other factors. Planning for establishment should begin at least one or more years in advance so that soil deficiencies (e.g. low pH) can be corrected or to control weed populations through appropriate crop rotation along with herbicide use.

Other important considerations in the planning process are to consider if the proposed crop rotation has the flexibility to respond to markets or climate with alternative crop choices. Producers should also consider risk assessment and the probability of success and to be completely aware of potential to realize all 
outcomes. Risk management practices such as participation in government incentive programs [e.g., the biomass crop assistance program (BCAP)], and the availability of crop insurance should also be considered. In the USA, the BCAP program provides eligible producers reimbursement of up to $75 \%$ of the cost of establishing a perennial bioenergy crop along with assistance (up to $\$ 45$ per ton) for harvest, transport, and storage of bioenergy crops. Risk management also applies to harvest decisions. Harvesting switchgrass early to obtain quality forage for livestock and using regrowth for biomass may provide flexibility for the producer but can risk stand longevity and future productivity. Managing for a single autumn harvest can maximize yield, whereas allowing the stand to remain in the field over winter to reduce mineral and water levels for efficient harvest and storage risks yield loss.

Proper management is needed to realize the best yields possible for a given land area so as not to replace (or reduce) or compete with land for food production [9]. The importance of proper management was illustrated by Lemus et al. [10] who showed that simply improving agronomic management by controlling weeds and implementing a standard harvest schedule (without $\mathrm{N}$ fertilizer) increased yields from 2.3 to $5 \mathrm{Mg} \mathrm{ha}^{-1}$.

Implementing appropriate management practices can be an important part of reducing production risk. Appropriate establishment techniques protect against risk of stand failure. Use of best management practices positions the farmer for the best yield response in favorable growing conditions. Similarly, implementing best practices can protect against losses from pests, diseases, and abiotic stresses.

\subsection{Switchgrass Establishment}

\subsubsection{Site Selection and Preparation}

Like most perennial species, switchgrass establishes best on well-drained, fertile soils but it also can establish and persist under highly variable soil conditions. Switchgrass used in bioenergy is likely to be grown on land that is unsuitable for crop production either based on erosion potential or low crop productivity. Switchgrass establishment practices for bioenergy plantings will require rapid establishment and effective weed control.

Proper planning is important for establishment success. Key factors to consider for successful establishment are measuring soil fertility status, proper field preparation, proper cultivar selection, and using high quality seed. Soil sampling before planting is recommended to determine soil nutrient status with the number of soil samples required being dependent on the soil heterogeneity of the land to be converted. At a minimum, soil should be tested for $\mathrm{P}, \mathrm{K}$, and $\mathrm{pH}$ before planting with subsequent soil sampling every three to five years thereafter. Optimal seed germination occurs between $\mathrm{pH}$ of 6-8 [11] but switchgrass seedlings can tolerate 
$\mathrm{pH}$ values between 3.7 and 7.6 under field conditions [5, 12, 13]. The overall effectiveness of liming before switchgrass establishment has been mixed but liming is likely beneficial on soils with $\mathrm{pH}$ values below 5.0 [13].

Planting switchgrass into existing cropland, pastureland, or conservation land requires land management preparation one to two years in advance. For example, scouting for and controlling perennial weeds within fields before switchgrass establishment will minimize stand failures. Allelopathic effects from previous crops on switchgrass establishment have not been well documented but certain crops can increase or decrease the likelihood of successful establishment depending on weed suppression, herbicide carryover, and residue amount. Herbicide-resistant crops in general provide good weed suppression the following year for effective establishment. For example, soybean (Glycine max L. Merr.) provides a firm seed bed, minimal residue, and good weed control which are important attributes for successful establishment of switchgrass. High-residue crops, such as maize (Zea mays L.) may require heavy duty drills to plant switchgrass under no-till conditions or tillage practices for effective seed-to-soil placement and uniform seeding depth. Establishing switchgrass in former pastureland or conservation land is more challenging and requires multiple management tools such as non-selective herbicides, tillage, and burning.

\subsubsection{Cultivar Selection}

Selecting the proper cultivar is critical for both establishment and persistence. Switchgrass cultivars are morphologically divided into upland and lowland ecotypes (see Chap. 1). Lowland ecotypes are taller, have longer more bluish-green leaves, have longer ligules, are higher yielding, grow like a bunchgrass, are more rust (Puccinia emaculata Schwein.; Puccinia graminis Pers.; Uromyces gramincola Burrill) resistant, and have a coarser stem than upland ecotypes. Upland ecotypes are shorter growing, have a finer stem, and are more tolerant of dry climatic conditions than lowland ecotypes [4]. Within ecotypes there are northern upland, southern upland, northern lowland, and southern lowland strains based on responses to latitudinal effects [14]. Viable switchgrass seed can be produced when lowland ecotypes and upland ecotypes are crossed with the same chromosome number [15]. Development of F1 hybrids derived from upland and lowland ecotypes has shown increased biomass yields compared with the parental lines [16].

Estimates of economic yields of switchgrass biomass vary, but McLaughlin et al. [17] indicated that $9 \mathrm{Mg} \mathrm{ha}^{-1}$ average annual yield across all production areas was economic in the USA. In a meta-analysis of switchgrass biomass yields from 39 sites in 17 states of the USA, lowland ecotypes of switchgrass averaged $12.0 \pm 5.9 \mathrm{Mg} \mathrm{ha}^{-1}$ and upland ecotypes averaged $8.7 \pm 4.2 \mathrm{Mg} \mathrm{ha}^{-1}$ (Fig. 4.1; [18]). Based on their empirical model of switchgrass yield, greatest biomass yields were predicted to occur in a region from the mid-Atlantic region to eastern Kansas and Oklahoma. 


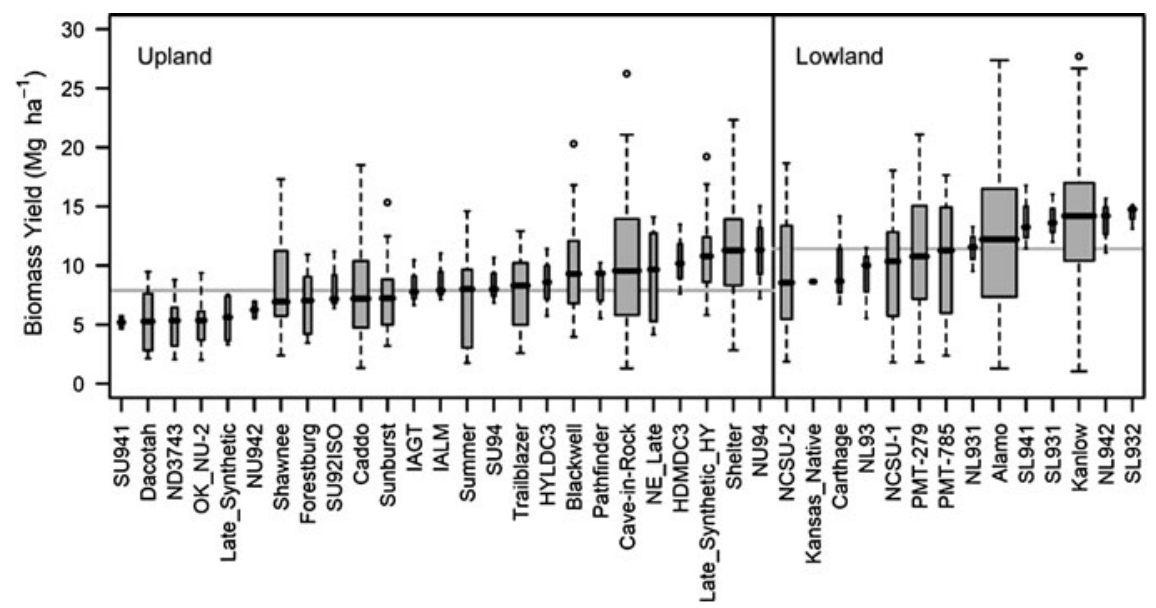

Fig. 4.1 Variation in biomass yields of upland and lowland switchgrasses at several locations in the USA (from Wullschleger et al. [18], with permission, copyright American Society of Agronomy)

European research also indicates that lowland ecotypes yielded more than upland ecotypes. Averaged over four years and two systems of cutting in Italy, lowland ecotypes averaged $14.9 \mathrm{Mg} \mathrm{ha}^{-1}$, whereas upland ecotypes averaged $11.7 \mathrm{Mg} \mathrm{ha}^{-1}$ [19]. Yields for several switchgrass varieties ranged from 7.1 to 21.3 $\mathrm{Mg} \mathrm{ha}^{-1}$ during four years in Greece and 0.9-26.1 $\mathrm{Mg} \mathrm{ha}^{-1}$ in Italy [20].

Switchgrass is photoperiod sensitive, requiring short days to induce flowering [21]; however, there is variation among switchgrass cultivars in photoperiod response [22, 23]. When switchgrass is grown north of the original adaptation area, it is exposed to longer photoperiods resulting in a longer vegetative stage and more biomass is produced than existing populations originating within that latitudinal environment. Switchgrass populations moved south of their original adaptation area produce less biomass than in their original adaptation area because floral initiation begins earlier. Switchgrass populations moved too far north in a temperate climate do not survive the winter because the plants do not cold harden before the onset of freezing temperatures. Switchgrass populations that originated in high latitudes or low latitudes within the United States have the most defined plant responses to latitude [14]. Generally, switchgrass cultivars should not be planted more than one hardiness zone (Fig. 4.2) north of their area of origin [4, 24]. Longitudinal response by switchgrass populations is less defined than latitudinal responses and is variety specific [24].

The optimal latitude for growing a specific switchgrass variety will also differ between Europe and North America. For example, the cultivar Cave-in-Rock, which originates in southern Illinois USA $\left(38.30^{\circ}\right.$ North), is probably best adapted to northwest Europe (Netherlands and United Kingdom 52 North) [25]. When cultivars are grown too far north, they may not survive winter or have reduced 


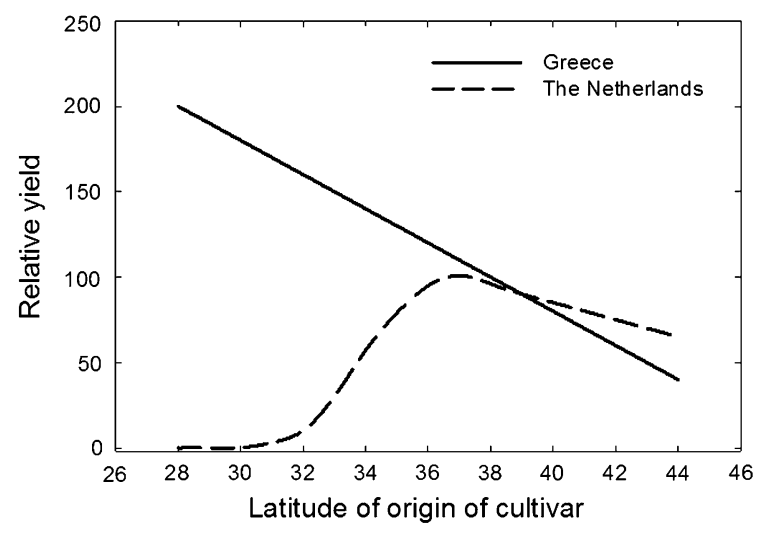

Fig. 4.2 Expected relative yields of varieties from low and high latitude of origin when grown at a Northern location $\left(52^{\circ}\right.$ north, the Netherlands) and at a southern location $\left(38^{\circ}\right.$, Greece) (from Elbersen, with permission)

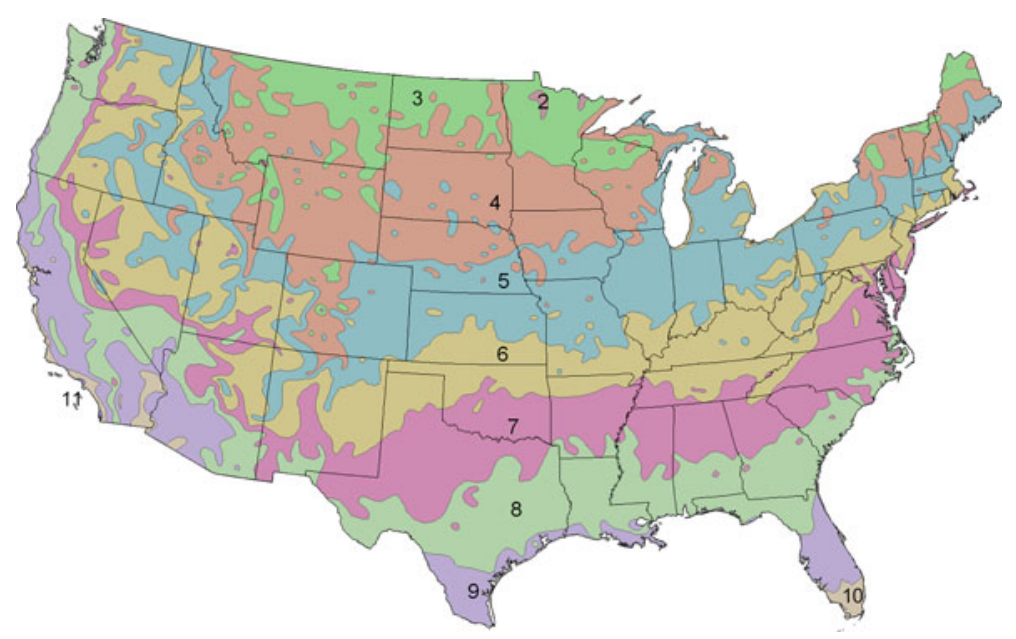

Fig. 4.3 USDA plant hardiness zones for the 48 contiguous states in the USA (http:// www.usna.usda.gov/Hardzone/ushzmap.html). Switchgrass cultivars should not be planted more than one hardiness zone north of their area of origin. The average minimum annual temperature $\left({ }^{\circ} \mathrm{C}\right)$ ranges by zone: zone $1,<-45.6$; zone $2,-45.5$ to -40 ; zone $3,-39.9$ to -34.5 ; zone 4 , -34.5 to -28.9 ; zone $5,-28.8$ to -23.4 ; zone $6,-23.3$ to -17.8 ; zone $7,-17.7$ to -12.3 ; zone $8,-12.2$ to -6.7 ; zone $9,-6.6$ to -1.2 ; zone $10,-1.1$ to 4.4 ; zone $11,>4.5$

stand life. A generalized relationship between latitude of origin of a cultivar and the yield at a southern and northern site in Europe is illustrated in Fig. 4.3.

Cultivars originating from the semi-arid Great Plains may be more susceptible to disease when established in more humid locations, whereas cultivars originating in humid climates may be less adapted to the drought conditions of semi-arid 


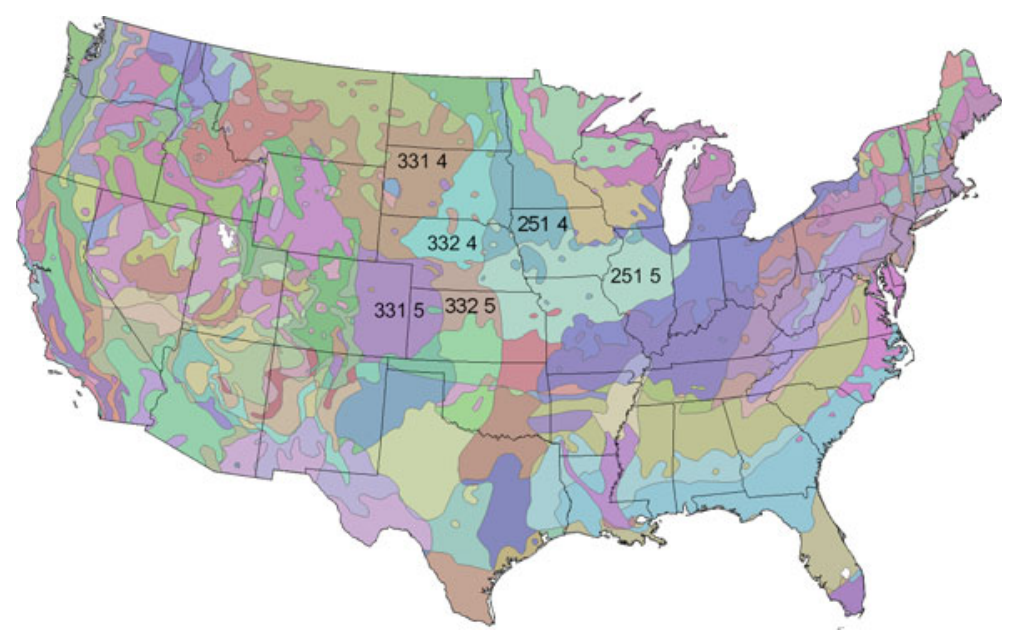

Fig. 4.4 Plant adaptation region map for the 48 contiguous states of the USA (from [26]). Plant adaptation regions are derived from combining ecoregion and plant hardiness zone classification systems. Example plant adaptation regions labeled include the Great Plains Steppe hardiness zones 4 and 5 (331-4, 331-5, 331-5, and 332-5) and the Prairie Parkland Temperate hardiness zones 4 and 5 (251-4 and 251-5)

climates. Plant adaptation regions define suitable environments for leading switchgrass populations (Fig. 4.4, [26]).

The majority of released switchgrass cultivars were developed for conservation or traits desirable for pasture grazing. Current switchgrass varieties tend to be from (1) seed increases from random plants originating from a remnant prairie or (2) improved cultivars based on selection of defined traits such as yield, digestibility, seed dormancy, or disease resistance [27], see Chap. 2]. Most improved switchgrass cultivars have been developed in the Central Plains of the USA. Breeding for specific bioenergy traits (e.g. low lignin, high cellulose) will be dependent on the conversion process used within a given region [1].

\subsubsection{Seed Quality}

Seed quality attributes include viability, purity, cleanliness, and vigor [28]. Seed vigor relates to the ability of a seed to germinate and establish a viable seedling under field conditions (see Chap. 3). Growing conditions, harvest timing, seed drying, cleaning and processing procedures, storage conditions, field sanitation, diseases, and insects influence switchgrass seed quality [28]. Agronomic practices that improve seed quality include $\mathrm{N}$ fertilization, use of row cultivation, spring burning, and control of smut (Tilletia maclaganii (Berk.) G.P. Clinton) and rust. Selection for increased seed size can increase viability and vigor. Average seed 
weight for switchgrass is 850 seeds $\mathrm{g}^{-1}$ but variation exists among and within cultivars for seed size [5]. High germination rates and greater emergence have been reported for switchgrass seed with higher than average seed weights [29, 30]. Under field conditions, switchgrass seedlings from heavy seed had greater germination and earlier growth than lighter seed but no growth differences were detected 8-10 week after emergence [31].

\subsubsection{Seed Quality Tests}

Standard germination and purity tests have limited utility in the direct calculation of planting rates for switchgrass. Pure live seed (PLS) is used in expressing seed quality and determining recommended field seeding rates. Pure live seed is calculated as: PLS $(\%)=[$ seed purity $(\%) \times$ seed germination $(\%)] / 100$. Switchgrass germination testing protocols from the Association of Official Seed Analysts include a 14 day cold stratification $\left(5^{\circ} \mathrm{C}\right)$ period before germination testing, which reduces the amount of primary dormancy found in switchgrass. The germination percentage found on seed tags tends to overestimate the percent of viable seeds, which complicates determining proper field seeding rates [13]. Germination trials without cold stratification are recommended if seed dormancy is expected [5]. Seed vigor tests that evaluate emergence from depth or accelerated aging tests have been recommended as alternative methods in determining field seeding rates $[32,33]$. Switchgrass seed lots with the same germination percentage but different seedling vigor have resulted in emergence differences of more than $40 \%$ [28].

\subsubsection{Dormancy}

Seed dormancy reduces seedling vigor and establishment. Dormant seed can be defined as seed that is unable to germinate even when subjected to suitable conditions [34]. The mechanisms for seed dormancy of switchgrass are complex but the expression of seed dormancy is caused by structures that surround the embryo and mechanisms within the embryo [35]. Dormancy is likely caused by genetics and environmental effects during seed production, harvesting, and processing. Genetic selection for low dormancy seed has been shown to lower overall primary dormancy in lowland ecotypes [36]. Primary dormancy of switchgrass seed can generally be broken by an after-ripening period or by cold stratification [4]. After-ripened switchgrass seed is generally one-year-old or more. Switchgrass seed that is stored for three or more years at room temperature may have poor seedling vigor and reduced establishment [28]. Secondary or latent dormancy occurs when viable seed becomes dormant after unfavorable environmental conditions [35]. Environmental or chemical methods can be used to break secondary dormancy. Seeds that have undergone secondary dormancy-breaking techniques but still demonstrate low germination have residual dormancy [37]. Residual dormancy can be reduced in switchgrass when endogenous levels of nitric oxide 
(NO) and reactive oxygen species (ROS) are altered [38]. High abscisic acid (ABA) levels can increase dormancy in monocot seeds [39]. Exogenous ABA and diphenyleneiodonium levels in switchgrass seeds are believed to block germination by restricting ROS and NO activity [38]. Gibberellic acid, sodium nitroprusside, potassium ferrocyanide, potassium nitrate, polyethylene glycol, and hydrogen peroxide have been used to reduce residual dormancy in switchgrass but overall success of each treatment is cultivar-specific [40, 41].

\subsubsection{Seed Treatments}

Several seed treatments have been investigated for their ability to increase switchgrass germination and establishment. Seed priming, an osmotic process where seed is hydrated to a level where metabolic activity begins but radicle emergence does not occur, may enhance switchgrass germination [42, 43]. Seed water uptake is regulated when priming media such as synthetic calcium silicate is used as a water source until equilibrium between the seed and media is reached. Hydrogen peroxide treatment of non-dormant switchgrass seeds increased seed germination and emergence along with more uniform development of seedlings [38]. Sodium nitroprusside, a NO donor, promoted germination of the lowland ecotype Kanlow [37]. Field conditions at planting influenced overall effectiveness of primed seed [42]. Blending primed and non-primed seed may reduce overall seeding costs and increase stand establishment under variable field conditions [44]. Karrikinolide [3-methyl-2H-furo[2,3-c]pyran-2-one], a compound from smoke that has been found to promote germination and seedling establishment in several native species, did not increase switchgrass germination or seedling vigor [45]. Switchgrass seeds coated with fungicides have been used in humid climates to increase seedling emergence; however, it is unclear if fungicide application limits the symbiotic relationship between switchgrass and arbuscular mycorrhizal fungi. Insecticides have also been shown to improve establishment [46] and can be used as a seed coating applied before planting.

\subsubsection{Seedbed Preparation}

Switchgrass can grow under variable soil conditions ranging from sand to clay loam [5]. Switchgrass has been successfully established under various tillage practices but side-by-side tillage studies and preceding crop comparisons have been limited [13]. Switchgrass is mainly established through direct seeding using a culti-packer seeder, grain drill, or no-till drill. Seed-drill calibration is necessary to ensure proper seeding rates. Broadcast seeding also has been used in conservation plantings but lack of stand uniformity may limit its potential use for bioenergy plantings. Seedbed preparation likely will be predicated on equipment accessibility, soil erosion concerns, preceding crop, and initial soil moisture conditions. 
A firm seed bed is recommended for proper seed placement regardless of planting method since switchgrass is planted at a shallow depth. Planting switchgrass using conventional tillage methods is a common practice for effective establishment. A grain drill with a small-seed box and small-seed tube attachment or a cultipacker seeder is effective in establishing switchgrass under conventional tillage practices. Conventional tillage can control or reduce cool-season weed populations before seeding as well as reduce residue from previous cropping systems that may interfere with proper seed placement. Soil temperatures will be higher under conventional tillage than no-tillage practices during a spring seeding. Following a tillage practice, soil clods need to be reduced or eliminated by successive tillage, packing, or firming the soil to provide good seed-to-soil contact at time of planting. Soil firming before seeding has been more effective in switchgrass establishment than soil firming after seeding [47]. Conventional tillage practices are not recommended on fields with steep slopes because of the risk of soil erosion. Soil carbon loss via $\mathrm{CO}_{2}$ emissions from tilled soil is also a concern, especially on land that was previously in set-aside programs or other perennial grassland systems which tend to maintain high levels of soil carbon [48]. No-tillage seeding of switchgrass has also been effective under variable climate conditions and previous cropping systems. No-tillage practices have been successful in establishing switchgrass in existing grasslands and are highly effective on soybean stubble [49]. A no-till drill is recommended when planting in sod or heavy residue because the drill has coulters to remove residue before seed placement and it is heavier than a conventional grain drill. No-tillage seeding provides greater water conservation benefits than conventional tillage especially near the soil surface. For bioenergy purposes, both pre-emergent and post-emergent herbicides are critical under no-tillage practices to control or reduce weed populations during the establishment year.

\subsubsection{Fertilization}

Nitrogen fertilizer is not recommended during the planting year because $\mathrm{N}$ will encourage weed growth, increase competition for establishing seedlings, increase establishment cost, and increase economic risk associated with establishment if stands should fail [49]. Sanderson and Reed [50] found that there was no biomass yield response to $\mathrm{N}$ at rates of 22 or $112 \mathrm{~kg} \mathrm{ha}^{-1}$ during the establishment year of switchgrass and indicated that switchgrass was able to use the available $\mathrm{N}$ found in the soil during the establishment year. Starter fertilizer $\left(9 \mathrm{~kg} \mathrm{~N} \mathrm{ha}^{-1}\right.$ and $27 \mathrm{~kg} \mathrm{P}$ $\mathrm{ha}^{-1}$ ) applied at planting did not improve switchgrass establishment or initial yields [51]. As stated earlier, soil tests $(\mathrm{P}, \mathrm{K}, \mathrm{pH})$ are recommended before planting. Phosphorus levels (Bray \& Kurtz \#1 method) should exceed $25 \mathrm{mg} \mathrm{kg}^{-1}$ when establishing warm-season grasses [52, 53]. Phosphorus and K levels are generally adequate for switchgrass growth in most agricultural fields. 


\subsubsection{When to Plant}

Successful establishment of switchgrass seedlings is determined by seeding depth, soil texture, soil moisture, and soil temperature [13]. Soil temperatures above $20^{\circ} \mathrm{C}$ are required for switchgrass germination and seedling growth [54, 55]. Optimal germination of several switchgrass cultivars was found to be between 27 and $30^{\circ} \mathrm{C}$ [56] but germination tolerance to temperature varies by cultivar [57]. Switchgrass has a panicoid type of seedling root development (see Chap. 3) which places the crown node (from which adventitious roots develop) near the soil surface by elongation of the subcoleptile internode or mesocotyl [58]. The subcoleoptile internode has a relatively small xylem cross-sectional area in most warm-season grasses. This limits the amount of water and nutrients that can be transported from the primary root system to developing leaf area and contributes to seed establishment failure in warm-season grasses before adventitious roots develop [59]. Selection for low crown node placement (i.e., a shorter subcoleoptile internode) increased switchgrass seedling survival in the southern Great Plains [60]. Greater planting depths reduce warm-season seedling emergence [61]. Recommended planting depths for switchgrass are $0.5-2 \mathrm{~cm}$ [4] but seeding depths of $3 \mathrm{~cm}$ have been recommended on coarse textured soils [13].

The most important factor for switchgrass to develop adventitious roots is adequate soil surface moisture over a period of time [62]. Rainfall frequencies between 7 and 10 days were found to be crucial for seedling survival under south central US climate conditions [63]. Under favorable environmental conditions, warm-season grasses initiate adventitious roots at 2-4 weeks after emergence [59]. Switchgrass will typically have one adventitious root by the three-leaf emergence stage [62]. Adventitious roots have a larger xylem cross-sectional area than the subcoleoptile internode resulting in higher water uptake and nutrient absorption than the primary root system [59].

Seeding dates for warm-season grasses are recommended in early spring when soil moisture is not limiting and soil temperatures are low enough to cold-stratify seeds. For the Northeast United States, switchgrass planting is recommended 3 weeks before and 3 weeks after corn planting [64]. In Iowa, switchgrass planted in mid-April to early May had higher dry matter production than when planted later in the season [65]. Planting during late April to mid-May was optimum for warm-season grasses in mid-latitude areas of the United States [54, 55]. In Nebraska, planting in March resulted in higher standing crop biomass than April or May plantings [66]. Dormant planting (late autumn) or frost seeding (late winter) may be used to establish switchgrass for conservation purposes.

\subsubsection{Seeding Rate}

Recommended seeding rates for switchgrass are 200-400 pure live seeds (PLS) $\mathrm{m}^{-2}$. With excellent weed control, however, a seeding rate of 107 PLS m$~^{-2}$ gave adequate stands for conservation plantings [67]. Seeding rates of $4.48-11.20 \mathrm{~kg} \mathrm{ha}^{-1}$ resulted 
in similar biomass yields during post-establishment years in the southeast US [68]. Lower seeding rates are recommended for regions with limited rainfall but this recommendation is based on conservation plantings and may not be appropriate for bioenergy-specific plantings. Switchgrass swards appear to regulate plant density depending on the climate conditions and initial seedling density with low seedling density tending to increase with sward age and high seedling density tending to decrease until equilibrium has been reached for a particular site.

\subsubsection{Mixed Species Planting}

Mixed species plantings are common for conservation and forage purposes and may be useful for bioenergy purposes as well. The use of low-input high-diversity mixtures has been proposed as a sustainable way to produce bioenergy on degraded land [69]. Species and cultivar selection is important for long-term success and should have similar growth characteristics, seed vigor, forage quality characteristics, maturity dates, and tolerance to selected herbicides. Warm-season grass species of big bluestem (Andropogon gerardii Vitman), indiangrass [Sorghastrum nutans (L.) Nash], switchgrass and little bluestem [Schizachyrium scoparium (Michx.) Nash] were the dominant species of tallgrass prairie in North America. These species are common in mixtures for set-aside plantings within the central US. A positive relationship has been found between soil heterogeneity and plant diversity for grassland ecosystems. Planting mixed species would likely increase establishment success on areas with variable soil types or topography by allowing certain species to grow based on broad or narrow niche requirements. When switchgrass is planted as a mixture with other perennial grasses, it is recommended that no more than $20 \%$ of the seeds should be switchgrass [5].

In a multilocation study in Minnesota, biomass yield increased by $28 \%$ when species richness of mixtures increased from 1 to 8 species; however, there was no further yield increase at species richness levels of 8-24 species [70]. In most instances, only a few species produced most of the biomass yield. A comparison of warm-season grass monocultures with polycultures of 4-16 species of grasses and forbs demonstrated that monocultures produced more biomass more economically than polycultures [71]. Observational research on conservation grasslands in the northeastern USA indicated a negative relationship between plant species diversity and biomass production [72].

Companion crops have been used successfully to establish perennial grasses especially when herbicide options are limited. Advantages to companion crops include reduced erosion potential under conventional tillage along with a potential cash crop that can be harvested, which may reduce overall establishment costs especially if a switchgrass stand failure occurs. Companion crops also reduce weed populations during switchgrass establishment but management practices are important to ensure proper establishment. A disadvantage to using companion crops is that in certain regions, an establishment year switchgrass harvest is not 
possible because of limited biomass. Switchgrass has been successfully established under maize and sorghum-sudangrass (Sorghum bicolor $\times$ sudanense) $[73,74]$. Winter wheat (Triticum aestivum L.), spring oat (Avena sativa L.) and other annual cool-season grasses managed as a hay crop have been successfully used for establishing perennial grasses like switchgrass. Soybean planted in wide rows $(76 \mathrm{~cm})$ can be used in cooler regions where row canopy closure is delayed until late-summer. Seeding densities for the companion crop should be reduced from optimal monoculture plantings to allow more light to reach the switchgrass seedling.

Establishing switchgrass on land formerly in set-aside programs or pastures has been done using either conventional tillage or no-tillage methods [13]. Management practices for effective establishment may include autumn or spring hay harvest, prescribed burning in autumn or spring, pre- and post-herbicide treatments, tillage, and the use of companion crops. Planting set-aside land or pastures with herbicide-resistant soybeans or spring-planted cover crop mixtures one to two years before switchgrass establishment may also be an effective management tool for seedbed preparation.

\subsubsection{Weed and Pest Control During the Establishment Year}

Weed competition is a major reason for switchgrass stand failure during establishment. Acceptable switchgrass production can be delayed by one or more years by weed competition and poor stand establishment [75]. The most common weeds in establishing warm-season grasses are annual grasses such as crabgrass [Digitaria sanguinalis (L.) Scop.], green foxtail [Setaria viridis (L.) Beauv.], yellow foxtail [Setaria glauca (L.) Beauv.], autumn panicum (Pancicum dichotomiflorum Michx.), and barnyardgrass [Echinochloa crusgalli (L.) Beauv.] [76]. The recommended practice of controlling weeds in fields planted with switchgrass is with the use of pre-emergent herbicides particularly for annual grass control. Non-selective herbicides, such as glyphosate [ $\mathrm{N}$-(phosphonomethyl) glycine] are effective in weed control before switchgrass emergence especially under no-till plantings. It is important to follow all herbicide regulations, label directions, and safety precautions. Extension staff or professional advisors should be consulted regarding proper use and application of all herbicides.

Atrazine [2-chloro-N-ethyl-N'-(1-methylethyl)-1, 3, 5-triazine-2, 4-diamine] has been an effective herbicide during switchgrass establishment controlling mainly cool-season annual grasses and broadleaf weeds [65, 77]. Switchgrass biomass yields were higher with atrazine application than without [52, 77]. Quinclorac (3, 7-dichloro-8-quinolinecarboxylic acid) is another effective herbicide in establishing switchgrass [2, 78]. Quinclorac controls warm-season annual grasses such as giant foxtail [Setaria faberi (L.) Beauv.], yellow foxtail, green foxtail, and barnyardgrass along with a limited number of broadleaf species [79]. Switchgrass treated with a pre-emergent combination of quinclorac and atrazine 
had greater biomass yields and comparable switchgrass stand frequencies compared with switchgrass treated with atrazine or quinclorac alone and both herbicides were equally effective on upland and lowland ecotypes [80]. Post-emergent application of quinclorac reduced switchgrass yields compared with atrazine but was highly effective in controlling annual grasses [81]. Pre-emergent applications of imazethapyr \{2-[4,5-dihydro-4-methyl-4-(1-methlethyl)-5-oxo-1H-imidazol-2-yl]-5-ethyl3-pyridine-carboxylic acid\} has been effective in switchgrass establishment [82]. Post-emergent sulfosulfuron [1-(4,6-dimethoxypyrimidin-2-yl)-3-(2-ethylsulfonylimidazo[1,2-a]pyridin-3-yl)sulfonylurea] applications on switchgrass are more effective in controlling smooth pigweed (Amaranthus hybridus L.) than quinclorac but are less effective on annual grasses [78]. The use of 2,4-D (2,4-dichlorophenoxyacteic acid) is cost effective for broadleaf weed control when applied post-emergence at the 4- or 5-leaf stage. Broadleaf weed control using a mechanical treatment (mowing) can be successful when broadleaf weeds are taller than switchgrass and the mowing application can be done to minimize switchgrass leaf loss [83]. After successful establishment, only limited herbicide use should be necessary.

Research on pest and disease control on switchgrass grown for bioenergy has been limited. Establishment year insecticide applications like carbofuran (2,3-dihydro-2,2-dimethly-7-bensofuranyl) have had variable success on switchgrass yield and stands [13, 84]. Insect injury on switchgrass seedlings is dependent on climatic conditions, seeding dates, and weed populations. Outbreaks of rust and smut can occur during the establishment year but are generally more likely to occur post-establishment.

\subsubsection{How to Evaluate Establishment Success}

A grass seedling is considered fully established when adventitious roots are formed, able to overwinter, and survive the following growing season [85, 86]. Switchgrass seedlings must develop two or more tillers to survive winter [87]. At the field-scale, switchgrass stands are evaluated based on morphological development, weed control, and seedling density. Integrating a global position system receiver and the use of geographic information systems (GIS) with groundbased scouting tools can assist in quantifying stand densities and weed populations across fields. Maps can be generated using GIS-derived data to identify areas within fields for possible reseeding or weed control measures. Switchgrass will typically not reach full yield potential until 1-2 years after the establishment year. Under normal weather conditions and proper agronomic management, switchgrass can achieve $\geq 50 \%$ of full yield potential during the establishment year [75]. Harvesting switchgrass in the establishment year reduces farm-gate production costs and improves economic returns [88]. 
The definition of an acceptable stand density is dependent on the desired management goal. Stand densities of $\geq 10$ seedlings $\mathrm{m}^{-2}$ are acceptable for conservation purposes [89-91], whereas switchgrass managed for grazing or bioenergy purposes will require higher initial stand densities. Establishment year stands of $>20$ switchgrass seedlings $\mathrm{m}^{-2}$ with minimal weed pressure are considered to be fully successful, whereas stands between 10 and 20 seedlings $\mathrm{m}^{-2}$ are considered adequate, and stands below 10 seedlings $\mathrm{m}^{-2}$ may require reseeding. Switchgrass has the ability to produce similar biomass yield under different seedling densities as a result of compensatory responses to tiller number and sizes [50]. When comparing recommended seeding rates (200-400 PLS m${ }^{-2}$ ) and desired seedling densities, planted seed to established seedling success rate is generally $<20 \%$.

Stand frequency measurements have been used to quantify seeding establishment and assess grassland improvements [92, 93]. Frequency is determined by the number of samples in which a species occurs, within a given area, and is expressed as a percentage of the total. Vogel and Masters [93] developed a frequency grid tool that can be used to assess plant populations at numerous sampling areas within a field and provide a conservative estimate of stand density. In a study conducted in the northern Great Plains USA on 10 farms, switchgrass fields with stand frequency of $40 \%$ or greater provided a successful establishment year stand threshold for subsequent post planting year biomass yields [75]. The frequency grid tool was designed for monitoring plantings under culti-pack drop seeders or conventional seed drills. Switchgrass planted into wider drill rows $(>38 \mathrm{~cm})$ may require alternative methods to quantify establishment success, such as a frequency rod or line transects [77, 94].

\subsection{Soil Fertility and Crop Fertilization in the Established Stand}

Fertilizer requirements of switchgrass managed for bioenergy depend on yield potential, soil productivity, management practices, and weather. Most switchgrass fertility research has focused on $\mathrm{N}$ because it is often the most limiting nutrient [95-97], and before 1990 the primary goal was to better understand the effect of fertility on switchgrass grown for forage rather than bioenergy [98]. This is an important consideration because a biomass harvest, especially in northern environments, is often done around a killing frost in the autumn when some nutrients will have been translocated to underground tissue [99].

\subsubsection{Nitrogen}

Optimum $\mathrm{N}$ rates for switchgrass managed for bioenergy vary by geographic region, environmental and weather conditions (specifically precipitation), 
N-supplying capability of the soil, and harvest frequency [97, 100-103]. Maximum yields of 'Kanlow' switchgrass were achieved with $448 \mathrm{~kg} \mathrm{~N} \mathrm{ha}^{-1}$ applied in April in a 3-cut system in Oklahoma [97]. Multiple harvests each year and high $\mathrm{N}$ application rates, however, had a greater negative effect on average annual biomass production than a single harvest system over a four-year period at one of two study sites and was not economically feasible. Aravindhakshan et al. [100] concluded that harvesting once annually and applying only $69 \mathrm{~kg} \mathrm{~N}^{-1}$ was most economical in a similar environment. In a comparison of a 1- or 2-cut system with added $N\left(50 \mathrm{~kg} \mathrm{ha}^{-1}\right.$ with one cut or $100 \mathrm{~kg} \mathrm{ha}^{-1}$ with two cuts), Lemus et al. [102] noted that $\mathrm{N}$ removal was significantly greater in the 2-cut system because of the high concentration of $\mathrm{N}$ in the mid-summer harvest. Although mean switchgrass yields were slightly higher in the 2-cut, $100 \mathrm{~kg} \mathrm{~N} \mathrm{ha}^{-1}$ system than in a 1-cut, $50 \mathrm{~kg} \mathrm{~N} \mathrm{ha}^{-1}$ system, they concluded that the cost of additional inputs and greater $\mathrm{N}$ removal rates would not be worth the small yield increase. Applying $56 \mathrm{~kg} \mathrm{~N} \mathrm{ha}^{-1}$ increased switchgrass biomass production in several locations in South Dakota, USA, but application rates above this amount resulted in no further yield advantage and increased weed pressure [103]. Switchgrass response to $\mathrm{N}$ levels up to $220 \mathrm{~kg} \mathrm{ha}^{-1}$ was linear or quadratic in Iowa, USA [104].

Applying 10-12 $\mathrm{kg} \mathrm{N}^{-1}$ for each $\mathrm{Mg} \mathrm{ha}^{-1}$ biomass removed under a single late-summer or autumn harvest is recommended in the Midwest USA [99]. This allows for replacement of $\mathrm{N}$ removed in biomass because switchgrass typically contains $60-120 \mathrm{~kg} \mathrm{~N} \mathrm{Mg}^{-1}$. Regardless of amount applied, $\mathrm{N}$ is typically applied after green-up in the spring to minimize weed encroachment, particularly from invasive cool-season grasses.

Nitrogen response of switchgrass may depend on harvest management. For example, in western Europe, switchgrass generally is harvested after senescence in winter (i.e., delayed harvest) and yield response to $\mathrm{N}$ is minimal, even if the crop is grown for many years with no fertilizer $\mathrm{N}[105,106]$. The low $\mathrm{N}$ removal (because of $\mathrm{N}$ recycling within the plant) combined with high rates of atmospheric $\mathrm{N}$ deposition and generally high soil $\mathrm{N}$ levels probably contribute to the lack of a $\mathrm{N}$ response in delayed harvest switchgrass in Europe.

\subsubsection{Phosphorus and Potassium}

Less research has been done relative to $\mathrm{P}$ and $\mathrm{K}$ fertilization of switchgrass for biomass or forage. Recommendations for $\mathrm{P}$ and $\mathrm{K}$ application are based on soil test levels and soil characteristics, [101]. There was no response of switchgrass to $\mathrm{P}$ application at two locations in Texas, USA over a 3 or 7 year period [96]. Switchgrass production increased when $\mathrm{P}$ and $\mathrm{N}$ or $\mathrm{P}, \mathrm{K}$, and $\mathrm{N}$ were applied together with lime compared to $\mathrm{N}$ alone on five different soils in Louisiana, USA [107]; however, the authors speculated that response to $\mathrm{P}$ fertilization would be limited without $\mathrm{N}$. 
Switchgrass grown on acid soils $(\mathrm{pH}<5)$ may be subjected to $\mathrm{P}$ deficiencies. Switchgrass performs better on acid soils when grown in symbioses with arbuscular mycorrhizal fungi $[108,109]$. Phosphorus may be more available to plants with this association because arbuscular mycorrhizal fungi are better able to access more soil P.

\subsubsection{Lime}

Switchgrass has limited response to lime. In a greenhouse pot experiment with five acidic soils, yield did not increase when soil $\mathrm{pH}$ was brought to 6.5 with lime [107]. A yield response was noted, however, when $\mathrm{N}$ and $\mathrm{P}$ or N, P, and $\mathrm{K}$ were co-applied with lime. On a strongly acid (pH 4.3-4.9) soil in Pennsylvania, USA, untreated switchgrass yielded approximately $50 \%$ of that receiving the high lime and fertilizer rate [110].

\subsubsection{Manure}

Cattle manure may be used as a source of nutrients on switchgrass. Lee et al. [111] compared three equivalent $\mathrm{N}$ rates $\left(0,112\right.$, and $\left.224 \mathrm{~kg} \mathrm{ha}^{-1}\right)$ of cattle manure or ammonium nitrate and found that switchgrass yields increased with the medium application rate of either $\mathrm{N}$ source. However, ammonium nitrate had a greater deleterious effect on switchgrass stand persistence and weed encroachment than the equivalent rate of manure. They speculated that this may have been due to the slow release of $\mathrm{N}$ from manure compared to the rapid availability of $\mathrm{N}$ from ammonium nitrate. Switchgrass biomass yields increased linearly with dairy manure applied at rates of $0-600 \mathrm{~kg} \mathrm{~N} \mathrm{ha}^{-1}$ [112]. Switchgrass filter strips effectively reduced concentrations of nutrients and pollutants in runoff water from the dairy manure-treated plots.

\subsection{Pest and Weed Management in the Established Stand}

\subsubsection{Diseases}

A number of diseases have been reported in the literature for switchgrass. Disease pressure will likely increase if large scale production of switchgrass for bioenergy is realized [13]. Rust (Puccinia emaculata) has been found on switchgrass in central and eastern South Dakota. Rust symptoms have been more severe on cultivars of northern origin; however, heritability exists for rust resistance [113]. Other diseases reported in a review by Vogel [5] include anthracnose 
[Colletotrichum graminicola (CES) G.W. Wils; now suggested to be caused by Colletotricum navitas J.A. Crouch [114]], smuts [T. maclaganii (Berk.) G.P. Clinton], Phoma leaf spot (Phoma spp.), and Fursarium root rot (Fusarium spp.). Trailblazer switchgrass seemed to be more susceptible to anthracnose than Cavein-Rock in Pennsylvania [115]. Reduced switchgrass biomass and seed yields were attributed to smut in several production fields in Iowa, USA in the late 1990s [116]. Smut was found in 15 of 17 fields surveyed, and the authors estimated that $50-82 \%$ of the area in switchgrass production was infested with $T$. maclaganii. Fields with smut incidence $>50 \%$ yielded less than half of the expected biomass and some seed production fields were a total loss in 1999 [116]. Thomsen et al. [117] estimated yield losses from T. maclaganii of $2-40 \%$ in switchgrass fields sampled in Iowa, USA, and noted the critical need for research on disease management approaches if switchgrass is to be a successful biomass crop.

\subsubsection{Insects}

Few insects have been identified as potential pests of switchgrass; however, damage from insects may increase if or when switchgrass monocultures are grown on large production fields. Distribution and symptoms of a stem-boring caterpillar (Blastobasis repartella Dietz.) were described by Prasifka et al. [118]. In this survey $B$. repartella was consistently found in cultivated and natural switchgrass stands in eight northern states. In the four northern states (Illinois, Nebraska, South Dakota, and Wisconsin), sampling indicated that $1-7 \%$ of tillers were damaged by B. repartella [118]. A new species of gall midge [Chilophaga virgate Gagne (Diptera: Cecidomyiidae)] was recently discovered in South Dakota, USA [119]. Proportion of tillers infested with the gall midge in 10 switchgrass genotypes ranged from 7 to $22 \%$, mass of infested tillers was $35 \%$ lower than normal tillers, and infested tillers produced no appreciable seed. Grasshoppers (Orthoptera) are known to feed on switchgrass, but the extent of the damage has not been quantified [13].

\subsubsection{Weeds}

In established stands of switchgrass, weed pressure during the second growing season is often worse than in subsequent years if there was poor site occupancy by switchgrass seedlings during the seeding year. In that scenario, a number of weeds can become established during or after the first summer. The problem is often compounded because where site occupancy may not have been high during the seeding year, stand vigor still may be reduced in the second year and, therefore, vulnerability to weed competition may be increased. With adequate weed control during the first two years of a stand, subsequent problems with competition can be limited in switchgrass managed as a biofuel feedstock. 
Cool-season annual weeds usually are not a concern in switchgrass unless the infestation is severe. In such cases, use of either a broadleaf formulation (2,4-D, dicamba $\{3,6$-dichloro-2-methoxybenzoic acid\}, picloram $\{4$-amino-3,5,6-trichloro-2-pyridinecarboxylic acid $\}$, metsulfuron $\{2-[[[[(4-m e t h o x y-6-m e t h y l-1,3,5-$ triazin-2-yl)amino]carbonyl]amino]sulfonyl]benzoic acid\}, sulfosulfuron, or aminopyraild \{4-amino-3,6-dichloro-2-pyridinecarboxylic acid\} active ingredients) or a broad-spectrum herbicide, such as glyphosate, will provide effective control; where grasses are the concern, the latter is the proper choice. A burn-down chemical, such as paraquat $\left\{1,1^{\prime}\right.$-dimethyl-4, $4^{\prime}$-bipyridinium $\}$, is also an option in that instance. It is important to apply non-selective herbicides before the switchgrass breaks dormancy to avoid crop injury.

It is important to follow all herbicide regulations, label directions, and safety precautions. Extension staff or professional advisors should be consulted regarding proper use and application of all herbicides.

Cool-season perennial weeds are relatively easy to control in switchgrass because their growing season differs from that of switchgrass. Dormant-season applications of glyphosate can be used to control cool-season grasses. Switchgrass has modest tolerance to glyphosate early in the growing season [120], which allows some flexibility in terms of timing spring treatments. Regardless, it is best to use glyphosate before spring dormancy break or in autumn after switchgrass is fully dormant.

Summer annual weeds are usually not a problem unless the switchgrass stand density is low. Aggressive competitors such as crabgrass or seedling johnsongrass [Sorghum halapense L. (Pers)] usually will not establish and compete after switchgrass has developed a full canopy and is able to overtop these species. However, where grass weeds do persist imazethapyr [for crabgrass and signalgrass (Brachiaria platyphylla (Munro ex C. Wright) Nash)], quinclorac [for foxtails (Setaria species) and (Echinochloa crus-galli (L.) P. Beauv.)], or sulfosulfuron (for johnsongrass) can be useful, but generally must be applied when weeds are small $(6-20 \mathrm{~cm}$, depending on the weed species). Warm-season broadleaf weeds may be controlled with the same herbicides used during the cool-season, except that broad-spectrum chemicals should not be used once switchgrass is growing actively.

Low-growing summer perennial weeds often are not able to compete with wellestablished stands of switchgrass. Johnsongrass, on the other hand, can persist in switchgrass stands because of its tall growth habit. Lowland varieties of switchgrass typically will outcompete johnsongrass. Where that does not occur, and control is still necessary, sulfosulfuron can be effective. Perennial warm-season broadleaf weeds can be controlled with the same herbicides that are used to control cool- or warm-season annuals. With perennials, attention must be paid to stage of plant development because it affects application timing and rates.

As with any use of herbicides, attention should be paid to crops that may be planted on the site in the next 12 months because they may be sensitive to some herbicides. Also, there are some scenarios in which producers may want to use some part of the switchgrass crop otherwise intended for biofuels for livestock 
forage. In such cases, it is important to consider animal feeding restrictions stated on the herbicide label in deciding which product to use for weed control.

Early-season prescribed fire can also be effective for weed control [76]. Switchgrass should not be burned after mid-April, for the southerly and middle latitudes of the USA, so as not to reduce biomass yield [120]. There must be adequate fuel to carry a fire. In some cases, dense stands of early spring weeds, and the large amount of green vegetation they may produce, can hamper burning. Burning earlier (early to mid-March) may be effective before the weed cover becomes too dense. Clipping or mowing may be useful but will reduce yields if it occurs beyond the very early portion of the growing season. If there is a risk of a particularly undesirable weed going to seed or weeds otherwise reducing stand vigor or quality, clipping may be the desirable choice despite potential short-term reduction in yield.

\section{References}

1. Sanderson MA, Adler PR, Boateng AA, Casler MD, Sarath G (2006) Switchgrass as a biofuels feedstock in the USA. Can J Plant Sci 86:1315-1325

2. Mitchell RB, Vogel KP, Schmer MR, and Pennington D (2010) Switchgrass for biofuel production. Sustainable Ag energy community of practice, extension. Available at http:// extension.org/pages/Switchgrass_for_Biofuel_Production

3. Mitchell RB, Anderson BE (2008) Switchgrass, big bluestem, and indiangrass for grazing and hay. University of Nebraska-Lincoln Extension, IANR NebGuide G1908

4. Moser LE, Vogel KP (1995) Switchgrass, big bluestem, and indiangrass. In: Barnes RF (ed) Forages: an introduction to grassland agriculture. Iowa State University Press, Iowa

5. Vogel KP (2004) Switchgrass. In: Moser LE, Burson BL, Sollenberger LE (eds) Warmseason $\left(\mathrm{C}_{4}\right)$ grasses. ASA-CSSA-SSSA, Madison

6. Jensen K, Clark CD, Ellis P, English B, Menard J, Walsh M, de la Torre Ugarte D (2007) Farmer willingness to grow switchgrass for energy production. Biomass Bioenergy 31:773-781

7. Cope MA, McLarrerty S, Rhoads BL (2011) Farmer attitudes toward production of perennial energy grasses in east central Illinois: implications for community-based decision making. Annals Assoc Amer Geographers 101:852-862

8. Guretzky JA, Biermacher JT, Cook BJ, Kering MK, Mosali J (2010) Switchgrass for forage and bioenergy: harvest and nitrogen rate effects on biomass yields and nutrient composition. Plant Soil 339:69-81

9. Sinclair T (2009) Taking measure of biofuel limits. Amer Sci 97:400-407

10. Lemus R, Brummer EC, Burras CL, Moore KJ, Barker MF, Molstad NE (2008) Effects of nitrogen fertilization on biomass yield and quality in large fields of established switchgrass in southern Iowa, USA. Biomass Bioenergy 32:1187-1194

11. Hanson JD, Johnson HA (2005) Germination of switchgrass under various temperature and $\mathrm{pH}$ regimes. Seed Tech 27:203-210

12. McLaughlin S, Kszos AL (2005) Development of switchgrass as a bioenergy feedstock in the United States. Biomass Bioenergy 28:515-535

13. Parrish D, Fike J (2005) The biology and agronomy of switchgrass for biofuels. Crit Rev Plant Sci 24:423-459

14. Casler MD, Vogel KP, Taliaferro CM, Wynia RL (2004) Latitudinal adaptation of switchgrass populations. Crop Sci 44:293-303 
15. Martinez-Reyna JM, Vogel KP (2002) Incompatibility systems in switchgrass. Crop Sci 42:1800-1805

16. Vogel KP, Mitchell RB (2008) Heterosis in switchgrass: biomass yield in swards. Crop Sci 48:2159-2164

17. McLaughlin SB, de la Torre Ugarte DG, Garten CT Jr, Lynd LR, Sanderson MA, Tolbert VR, Wolf DD (2002) High-value renewable energy from prairie grasses. Environ Sci Technol 36:2122-2129

18. Wullschleger SD, Davis EB, Borsuk ME, Gunderson CA, Lynd LR (2010) Biomass production in switchgrass across the United States: database description and determinants of yield. Crop Sci 102:1158-1168

19. Monti A, Bezzi G, Pritoni G, Venturi G (2008) Long-term productivity of lowland and upland switchgrass cytotypes as affected by cutting frequency. Bioresour Technol 99:7425-7432

20. Alexopoulou E, Sharma N, Papatheohari Y, Christou M, Piscioneri I, Panoutsou C, Pignatelli V (2008) Biomass yields for upland and lowland switchgrass varieties grown in the Mediterranean region. Biomass Bioenergy 10:926-932

21. Benedict HM (1941) Effect of day length and temperature on the flowering and growth of four species of grasses. J Agric Res 61:661-672

22. Castro JC, Boe A, Lee DK (2011) A simple system for promoting flowering of upland switchgrass in the greenhouse. Crop Sci 51:2607-2614

23. Van Esbroeck GA, Hussey MA, Sanderson MA (2003) Variation between alamo and cavein-rock switchgrass in response to photo period extension. Crop Sci 43:639-643

24. Casler MD, Vogel KP, Taliaferro CM et al (2007) Latitudinal and longitudinal adaptation of switchgrass populations. Crop Sci 47:2249-2260

25. Elbersen HW, Christian DG, El Bassam N et al (2001) Switchgrass variety choice in Europe. Aspects Appl Biol 65:21-28

26. Vogel KP, Schmer MR, Mitchell RB (2005) Plant adaptation regions: ecological and climatic classification of plant materials. Rangeland Ecol Manag 58:315-319

27. Casler MD, Heaton EA, Shinners KJ et al (2009) Grasses and legumes for cellulosic bioenergy. In: Wedin WF, Fales SL (eds) Grassland: quietness and strength for a new American agriculture. ASA-CSSA-SSSA, Madison

28. Vogel KP (2002) The challenge: high quality seed of native plants to ensure successful establishment. Seed Tech 24:9-15

29. Aiken GE, Springer TL (1995) Seed size distribution, germination, and emergence of 6 switchgrass cultivars. J Range Manage 48:455-458

30. Green JC, Bransby DI (1995) Effects of seed size on germination and seedling growth of 'Alamo' switchgrass. In: West NE (ed) Proceedings of 5th international rangelands congress, Salt Lake City, UT, 1995. Society for range management

31. Smart AJ, Moser LE (1999) Switchgrass seedling development as affected by seed size. Agron J 91:335-338

32. Asay KH, Johnson DA (1980) Screening for improved stand establishment in Russian wild ryegrass. Can J Plant Sci 60:1171-1177

33. Hall RD, Wiesner LE (1990) Relationship between seed vigor tests and field performance of 'Regar' meadow bromegrass. Crop Sci 30:967-970

34. Bryant JA (1985) Seed physiology. Edward Arnold Publishers, London

35. Knapp AD (2000) An overview of seed dormancy in native warm-season grasses. In: Moore KJ, Anderson BE (eds) Native warm-season grasses: research trends and issues. CSSA Special Publ 30. CSSA and ASA, Madison

36. Sanderson MA, Reed RL, McLaughlin SB et al (1996) Switchgrass as a sustainable bioenergy crop. Bioresour Technol 56:83-93

37. Sarath G, Bethke P, Jones R, Baird L, Hou G, Mitchell R (2006) Nitric oxide accelerates seed germination in warm-season grasses. Planta 223:1154-1164

38. Sarath G, Hou G, Baird LM, Mitchell RB (2007) Reactive oxygen species, ABA and nitric oxide interactions on the germination of warm-season C4-grasses. Planta 226:697-708 
39. Gubler F, Millar AA, Jacobsen JV (2005) Dormancy release, ABA and pre-harvest sprouting. Curr Opin Plant Biol 8:183-187

40. Madakadze IC, Prithiviraj B, Madakadze RM et al (2000) Effect of preplant seed conditioning treatment on the germination of switchgrass (Panicum virgatum $\mathrm{L}$.). Seed Sci Tech 28:403-411

41. Sarath G, Mitchell RB (2008) Aged switchgrass seed lot's response to dormancy-breaking chemicals. Seed Tech 30:7-16

42. Beckman JJ, Moser LE, Kubik K, Waller SS (1993) Big bluestem and switchgrass establishment as influenced by seed priming. Agron J 85:199-202

43. Hacisalihoglu G (2008) Responses of three switchgrass (Panicum virgatum L.) cultivars to seed priming and differential aging conditions. Acta Agric Scand, Sec B-Soil Plant Sci 58:280-284

44. Debebe JM (2005) Warm-season grass germination and seedling development as affected by seed treatments. Ph.D. dissertation, University of Nebraska, Lincoln

45. George N (2009) Does karrikinolide improve the germination and seedling vigour of switchgrass? Seed Sci Tech 37:251-254

46. McKenna JR, Wolf DD, Lentner M (1991) No-till warm-season grass establishment as affected by atrazine and carbofuran. Agron J 83:311-316

47. Monti A, Venturi P, Elbersen HW (2001) Evaluation of the establishment of lowland and upland switchgrass (Panicum virgatum L.) varieties under different tillage and seedbed conditions in northern Italy. Soil Till Res 63:75-83

48. Fargione J, Hill J, Tilman D, Polasky S, Hawthorne P (2008) Land clearing and the biofuel carbon debt. Science 319:1235-1238

49. Mitchell RB, Vogel KP, Sarath G (2008) Managing and enhancing switchgrass as a bioenergy feedstock. Biofuel Bioprod Bior 2:530-539

50. Sanderson MA, Reed RL (2000) Switchgrass growth and development: water, nitrogen, and plant density effects. J Range Manage 53:221-227

51. Warnes DD, Newell LC, Moline WJ (1971) Performance evaluation of some warm-season prairie grasses in Nebraska environments. Research Bulletin, Nebraska Agricultural Experiment Station

52. Rehm GW (1984) Yield and quality of a warm-season grass mixture treated with N, P, and atrazine. Agron J 76:731-734

53. Rehm GW, Sorenson RC, Moline WJ (1976) Time and rate of fertilizer application for seeded warm-season and bluegrass pastures: I. Yield and botanical composition. Agron J 68:559-564

54. Hsu FH, Nelson CJ (1986) Planting date effects on seedling development of perennial warm-season forage grasses. I field emergence. Agron J 78:33-38

55. Hsu FH, Nelson CJ (1986) Planting date effects on seedling development of perennial warm-season forage grasses. II seedling growth. Agron J 78:38-42

56. Dierberger BL (1991) Switchgrass germination as influenced by temperature, chilling, cultivar and seedlot. M.S. thesis, University of Nebraska, Lincoln

57. Seepaul R, Macoon B, Reddy KR, Baldwin B (2011) Switchgrass (Panicum virgatum L.) intraspecific variation and thermo tolerance classification using in vitro seed germination assay. Amer J Plant Sci 2:134-147

58. Hoshikawa K (1969) Underground organs of the seedling and the systematics of gramineae. Bot Gaz 130:192-203

59. Moser LE (2000) Morphology of germinating and emerging warm-season grass seedlings. In: Moore KJ, Anderson BE (eds) Native warm-season grasses: research trends and issues. CSSA Spec. Publ 30 CSSA and ASA, Madison

60. Elbersen HW, Ocumpaugh WR, Hussey MA, Sanderson MA, Tischler CR (1999) Field evaluation of switchgrass seedlings divergently selected for crown node placement. Crop Sci 39:475-479

61. Newman PR, Moser LE (1988) Grass seedling emergence, morphology, and establishment as affected by planting depth. Agron J 80:383-387 
62. Newman PR, Moser LE (1988) Seedling root development and morphology of cool-season and warm-season forage grasses. Crop Sci 28:148-151

63. Ocumpaugh W, Hussey M, Read J et al (2003) Evaluation of switchgrass cultivars and cultural methods for biomass production in the southcentral U.S. Oak Ridge National Lab, Oak Ridge

64. Panciera MT, Jung GA (1984) Switchgrass establishment by conservation tillage: planting date responses of two varieties. J Soil Water Conserv 39:68-70

65. Vassey TL, George JR, Mullen RE (1985) Early-, mid-, and late-spring establishment of switchgrass at several seeding rates. Agron J 77:253-257

66. Smart AJ, Moser LE (1997) Morphological development of switchgrass as affected by planting date. Agron J 89:958-962

67. Vogel KP (1987) Seeding rates for establishing big bluestem and switchgrass with preemergence atrazine applications. Agron J 79:509-512

68. West DR, Kincer DR (2011) Yield of switchgrass as affected by seeding rates and dates. Biomass Bioenergy 35:4057-4059

69. Tilman D, Hill J, Lehman C (2006) Carbon-negative biofuels from low-input high-diversity grassland biomass. Science 314:1598-1600

70. Mangan ME, Sheaffer C, Wyse DL, Ehlke NJ, Reich PB (2011) Native perennial grassland species for bioenergy: establishment and biomass productivity. Agron J 103:509-519

71. Griffith AP, Epplin FM, Fuhlendorf SD, Gillen R (2011) A comparison of perennial polycultures and monocultures for producing biomass for biorefinery feedstock. Agron $\mathrm{J}$ 103:617-627

72. Adler PR, Sanderson MA, Weimer PJ, Vogel KP (2009) Plant species composition and biofuel yields of conservation grasslands. Ecol Appl 19:2202-2209

73. Cossar RD, Baldwin BS (2004) Establishment of switchgrass with sorghum-sudangrass. In: Randall J, Burns JC (eds). In: Proceedings of 3rd eastern native grass symposium, Chapel Hill, NC. Omnipress

74. Hintz RL, Harmoney KR, Moore KJ, George JR, Brummer EC (1998) Establishment of switchgrass and big bluestem in corn with atrazine. Agron J 90:591-596

75. Schmer MR, Vogel KP, Mitchell RB, Moser LE, Eskridge KM, Perrin RK (2006) Establishment stand thresholds for switchgrass grown as a bioenergy crop. Crop Sci 46:157-161

76. Mitchell RB, Britton CM (2000) Managing weeds to establish and maintain warm-season grasses. In: Moore KJ, Anderson BE (eds) Native warm-season grasses: research trends and issues. CSSA Spec. Publ. 30. CSSA and ASA, Madison

77. Martin AR, Moomaw RS, Vogel KP (1982) Warm-season grass establishment with atrazine. Agron J 74:916-920

78. Curran W, Ryan M, Myers M, Adler PR (2011) Effectiveness of sulfosulfuron and quinclorac for weed control during switchgrass (Panicum virgatum) establishment. Weed Technol 24:598-603

79. Masters RA, Sheley RL (2001) Principles and practices for managing rangeland invasive plants. J Range Manage 54:362-369

80. Mitchell RB, Vogel KP, Berdahl J, Masters RA (2010) Herbicides for establishing switchgrass in the central and northern Great Plains. Bioenerg Res 3:321-327

81. Boydston RA, Collins HP, Fransen SC (2010) Response of three switchgrass (Panicum virgatum) cultivars to mesotrione, quinclorac, and pendimethalin. Weed Technol 24:336-341

82. Masters RA, Nissen SJ, Gaussoin RE, Beran DD, Stougaard RN (1996) Imidazolinone herbicides improve restoration of Great Plains grasslands. Weed Technol 10:392-403

83. Elbersen HW, Christian DG, El Bassam N et al (2004) A management guide for planting and production of switchgrass as a biomass crop in Europe. In: van Swaaij WPM, Fjällström T, Helm P, Grassi A (eds) Proceedings of the 2nd world conference on biomass for energy, industry, and climate protection, Rome, Italy, 10-14 May 2004 
84. Bryan WB, Mills TA, Cronauer JA (1984) Sod-seeding switchgrass and tall fescue into hill land pasture. J. Soil Water Conserv 39:70-72

85. Hyder DN, Everson AC, Bement RE (1971) Seedling morphology and seeding failures with blue grama. J Range Manage 24:287-292

86. Whalley RD, McKell CM, Green LR (1966) Seedling vigor and the early nonphotosynthetic stage of seedling growth in grasses. Crop Sci 6:147-150

87. O'Brien TR, Moser LE, Masters RA, Smart AJ (2008) Morphological development and winter survival of switchgrass and big bluestem seedlings. Forage Grazinglands. doi:10.1094/FG-2008-1103-01-RS

88. Perrin R, Vogel K, Schmer M, Mitchell R (2008) Farm-scale production cost of switchgrass for biomass. Bioenerg Res 1:91-97

89. Cornelius DR (1944) Revegetation in the tall grass prairie region. J Am Soc Agron 36:393-400

90. Launchbaugh JL, Owensby CE (1970) Seed rate and first-year stand relationships for six native grasses. J Range Manage 23:414-417

91. Launchbaugh JL (1966) A stand establishment survey of grass plantings in the Great Plains. Nebraska Agric Exp Stn Great Plains Counc

92. Hyder DN, Sneva FA (1954) A method for rating the success of range seeding. J Range Manage 7:89-90

93. Vogel KP, Masters RA (2001) Frequency grid-a simple tool for measuring grassland establishment. J Range Manage 54:653-655

94. Samson JF, Moser LE (1982) Sod-seeding perennial grasses into Eastern Nebraska pastures. Agron J 74:1055-1060

95. Madakadze JC, Stewart K, Peterson PR, Coulman BE, Smith DL (1999) Cutting frequency and nitrogen fertilization effects on yield and nitrogen concentration of switchgrass in a short season area. Crop Sci 39:552-560

96. Muir JP, Sanderson MA, Ocumpaugh WR, Jones RM, Reed RL (2001) Biomass production of 'Alamo' switchgrass in response to nitrogen, phosphorus, and row spacing. Agron J 93:896-901

97. Thomason WE, Raun WR, Johnson GV, Taliaferro CM, Freeman KW, Wynn KJ, Mullen RW (2004) Switchgrass response to harvest frequency and time and rate of applied nitrogen. J Plant Nutr 27:1199-1266

98. Hall KE, George JR, Riedl RR (1982) Herbage dry matter yields of switchgrass, big bluestem, and indiangrass with $\mathrm{N}$ fertilization. Agron J 74:47-51

99. Vogel KP, Brejda JJ, Walters DT, Buxton DR (2002) Switchgrass biomass production in the Midwest USA: harvest and nitrogen management. Agron J 94:413-420

100. Aravindhakshan SC, Epplin FM, Taliaferro CM (2011) Switchgrass, bermudagrass, flaccidgrass, and lovegrass biomass yield response to nitrogen for single and double harvest. Biomass Bioenergy 35:308-319

101. Brejda JJ (2000) Fertilization of native warm-season grasses. In: Moore KJ, Anderson BE (eds) Native warm-season grasses: research trends and issues. CSSA Spec Publ 30. CSSA, Madison, WI

102. Lemus R, Parrish DJ, Wolf DD (2009) Nutrient uptake by 'Alamo' switchgrass used as an energy crop. Bioenerg Res 2:37-50

103. Mulkey VR, Owens VN, Lee DK (2006) Management of switchgrass-dominated conservation reserve program lands for biomass production in South Dakota. Crop Sci 46:712-720

104. Heggenstaller AH, Moore KJ, Liebman M, Anex RP (2009) Nitrogen influences biomass and nutrient partitioning by perennial, warm-season grasses. Agron J 101:1363-1371

105. Christian D, Riche AB, Yates NE (2002) The yield and composition of switchgrass and coastal panic grass grown as a biofuel in Southern England. Bioresour Technol 83:115-124

106. Lasorella MV, Monti A, Alexopoulou E et al (2011) Yield comparison between switchgrass and miscanthus based on multi-year side by side comparison in Europe. In: Proceedings of the 19th European biomass conference \& exhibition, Berlin 
107. Taylor RW, Allinson DW (1982) Response of three warm-season grasses to varying fertility levels on five soils. Can J Plant Sci 62:657-665

108. Clark RB, Baligar VC, Zobel RW (2005) Response of mycorrhizal switchgrass to phosphorus fractions in acidic soil. Comm Soil Sci Plant Anal 36:1337-1359

109. Clark RB (2002) Differences among mycorrhizal fungi for mineral uptake per root length of switchgrass grown in acidic soil. J Plant Nutr 25:1753-1772

110. Jung GA, Shaffer JA, Stout WL (1988) Switchgrass and big bluestem responses to amendments on strongly acid soil. Agron J 80:669-676

111. Lee DK, Owens VN, Doolittle JJ (2007) Switchgrass and soil carbon sequestration response to ammonium nitrate, manure, and harvest frequency on conservation reserve program land. Agron J 99:462-468

112. Sanderson MA, Jones RM, McFarland MJ, Stoup J, Reed RL, Muir JP (2001) Nutrient move-ment and removal in a switchgrass biomass-filter strip system treated with dairy manure. J Environ Qual 30:210-216

113. Gustafson DM, Boe A, Jin Y (2003) Genetic variation for Puccinia emaculata infection in switchgrass. Crop Sci 43:755-759

114. Crouch JA, Beim LA, Cortese LM, Bonos SA, Clarke BB (2010) Anthracnose disease of switchgrass caused by the novel fungal species colletotricum navitas. Mycol Res 113:1411-1421

115. Sanderson MA (2008) Upland switchgrass yield, nutritive value, and soil carbon changes under grazing and clipping. Agron J 100:510-516

116. Gravert CE, Tiffany LH, Munkvold GP (2000) Outbreak of smut caused by Tilletia maclaganii on cultivated switchgrass in Iowa. Plant Dis 84:596

117. Thomsen PM, Brummer EC, Shriver J, Munkvold GP (2008) Biomass yield reductions in switchgrass due to smut caused by Tilletia maclaganii. Plant Health Prog. doi:10.1094/PHP2008-0317-01-RS

118. Prasifka JR, Bradshaw JD, Boe AA, Lee DK, Adamski D, Gray ME (2010) Symptoms, distribution and abundance of the stem-boring caterpillar, Blastobasis repartella (Dietz), in switchgrass. Bioenerg Res 3:238-242

119. Boe A, Gagne RJ (2011) A new species of gall midge (Diptera: Cecidomyiidae) infesting switchgrass in the Northern Great Plains. Bioenerg Res 4:77-84

120. Sanderson MA, Schnabel RR, Curran WS, Stout WL, Genito D, Tracy BF (2004) Switchgrass and big bluestem hay, biomass, and seed yield response to fire and glyphosate treatment. Agron J 96:1688-1692 